\title{
PENGARUH PEMBELAHAN BIJI DAN JENIS MEDIA TERHADAP KEBERHASILAN SAMBUNG MIKRO MANGGIS (Garcinia mangostana L.) DI PESEMAIAN
}

\section{THE EFFECT OF SEED CLEAVAGE AND MEDIA TYPE ON THE SUCCESS OF MANGOSTEEN (Garcinia mangostana L.) MICROGRAFTING IN NURSERY}

\author{
Mira Agustina, Maisura, Hafifah, Laila Nazirah, Ismadi, dan Rd. Selvy Handayani* \\ Program Studi Magister Agroekoteknologi, Fakultas Pertanian, Universitas Malikussaleh, \\ Kampus Unimal, Cot Tengku Nie, Reuleut, Kabupaten Aceh Utara, Indonesia \\ *Email:selvy@unimal.ac.id
}

\begin{abstract}
Micro grafting techniques can be done in the nursery with the same plant conditions as in vitro micrografting. The advantage of in vitro micrografting from whole seed explants is that the success rate and plant growth are better than the shoots resulting from the germination of the split seeds. This research was conducted at the Laboratory of Plant Tissue Culture and Experimental Garden of Agriculture Faculty, Malikussaleh University. This research started from September 2018 to June 2019. The purpose of this research was to determine the effect of seed splitting for the source of rootstock and media types on the success of mangosteen micrografting in the nursery. This research used a two-factor randomized block design (RBD). The first factor is the source of rootstocks, which consists of 2 levels: the shoots produced from a whole seed nursery and shoots produced from halved seed nursery. The second factor is the type of media, which consists of 2 types: the soil planting medium and the sand planting medium with ten replications. The results showed that seed clavaged has an effect on reducing the success of mangosteen micro-grafting in nursery. The micro-grafted plants in the nursery came from the treatment of whole seeds have a faster sprouting time, new shoots higher, and new shoots are longer, and more leaves compared to halved seed treatment. Growing media treatment only had an effect on new shoot length variables. Soil media causes micro-grafted mangosteen plants in the nursery to have new shoots higher than the sand medium
\end{abstract}

Keywords: Mangosteen, microgafting, rootstock, scion, soil media.

\begin{abstract}
ABSTRAK
Teknik sambung mikro dapat dilakukan di pesemaian dengan kondisi tanaman yang sama seperti pada sambung mikro in vitro. Keunggulan sambung mikro in vitroeksplan biji utuh adalah tingkat keberhasilan dan pertumbuhan tanamannya lebih baik dibandingkan tunas dari perkecambahan biji dibelah. Penelitian ini dilakukan di Laboratorium Kultur Jaringan Tanaman dan Kebun Percobaan Fakultas Pertanian Universitas Malikussaleh.Penelitian ini dilaksanakan dari bulan September 2018 sampai dengan Juni 2019. Tujuan penelitian ini adalah untuk mengetahui pengaruh pembelahan biji untuk sumber batang bawah dan jenis media terhadap keberhasilan sambung mikro manggis di pesemaian. Percobaan ini menggunakan Rancangan Acak Kelompok (RAK) dua faktor. Faktor pertama adalah sumber batang bawah terdiri dari 2 taraf yaitu tunas dari pesemaian biji utuh dan tunas dari
\end{abstract}


pesemaian biji dibelah 2, Faktor kedua adalah jenis media tanam yaitu media tanam tanah dan media tanam pasir dengan 10 ulangan. Hasil penelitian menunjukkan bahwa pembelahan biji berpengaruh menurunkan keberhasilan sambung mikro manggis di pesemaian. Tanaman hasil sambung mikro di pesemaian yang berasal dari perlakuan biji utuh memiliki waktu tumbuh tunas lebih cepat, panjang tunas baru lebih tinggi dan jumlah daun lebih dibandingkan perlakuan biji dibelah dua. Perlakuan media hanya memberikan pengaruh pada peubah panjang tunas baru. Media tanah menyebabkan tanaman manggis hasil sambung mikro di pesemaian memiliki tunas baru lebih panjang daripada media pasir.

Kata kunci: Batang atas, batang bawah, manggis, media tanah, sambung mikro.

\section{PENDAHULUAN}

Indonesia terkenal dengan keanekaragaman jenis buah-buahan, salah satunya adalah buah manggis (Garcinia mangostana L.). Tanaman manggis merupakan salah satu komoditi hortikultura buahbuahan tropis asli Indonesia yang bernilai ekonomis tinggi serta mempunyai prospek cerah untuk diusahakan secara komersial. Manggis memiliki warna yang indah dan citarasa yang khas, bentuknya yang eksotik, sehingga sangat disukai konsumen.

Tanaman manggis mempunyai mekanisme reproduksi secara apomiksis (Sinaga et al., 2016). Perkembangan biji apomiksis terjadi tanpa proses kawin yang sempurna, sehingga hasil apomiksis merupakan suatu bentuk perbanyakan vegetatif. Penerapan bioteknologi melalui teknik irradiasi menjadi pilihan utama untuk menigkatkan keragaman tanaman. Penelitian irradiasi sinar gamma pada kultur kalus nodular telah dapat meningkatkan keragaman genetik, namun regeneran manggis hasil irradiasi tersebut belum berakar (Qosim et al., 2007).

Usaha pengakaran regeneran hasil irradiasi sinar gamma memerlukan teknik tertentu secara buatan misalnya sambung mikro. Teknik sambung mikro dapat menyebabkan regeneran hasil iradiasi menjadi berakar, dengan cara menyambungkan tunas yang belum berakar tersebut dengan batang bawah hasil perbanyakan in vitro yang sudah berakar.

Percobaan mengenai berbagai teknik sambung mikro secara in vitro banyak dilakukan sebelumnya pada berbagai tanaman, misalnya pada jambu mete (Ruhnayat dan Syakir, 2014), jeruk (Naz et al.,2007), ubi kayu (Rahman et al., 2017), dan manggis (Handayani et al., 2013; Agustina et al., 2020). Percobaan setek mikro juga sudah dilakukan pada berbagai tanaman dan berhasil menumbuhkan akar (Handayani, 2013; Handayani et al., 2020).

Teknik sambung mikro juga dapat dilakukan di pesemaian dengan kondisi tanaman yang sama seperti pada sambung mikro in vitro. Teknik sambung mikro akan memiliki laju pertumbuhan yang lebih baik dibandingkan grafting di lapangan (Handayani et al., 2013). Hal ini karena batang usia muda memiliki jaringan meristem yang lebih banyak, sehinga proses penyembuhan luka akibat sayatan pada saat penyambungan lebih cepat pulih (Tirtawinata, 2003).

Faktor yang berpengaruh dalam keberhasilan sambung mikro manggis di pesemian adalah biji dan media tanam. Pada sambung mikro in vitro, eksplan biji utuh menyebabkan keberhasilan dan pertumbuhan 
tanaman hasil sambung mikro yang lebih baik dibandingkan tunas dari perkecambahan biji yang dibelah empat (Handayani et al., 2013). Pada sambung mikro di pesemaian media tanam yang porous dapat menyebabkan tunas mikro berakar bahkan pada perlakuan tanpa diberi zat perangsang pertumbuhan akar (Handayani, 2012).

Penelitian ini akan membahas mengenai sambung mikro tanaman manggis yang ditanam di pesemaian. Tujuan penelitian ini adalah untuk mengetahui pengaruh pembelahan biji sebagai sumber batang bawah dan jenis media terhadap keberhasilan sambung mikro manggis di pesemaian.

\section{BAHAN DAN METODE}

Penelitian ini dilakukan di Laboratorium Kultur Jaringan Tanaman dan Kebun Percobaan Fakultas Pertanian Universitas Malikussaleh. Pelaksanaan penelitian dilakukan dari bulan September 2018 sampai dengan Juni 2019.
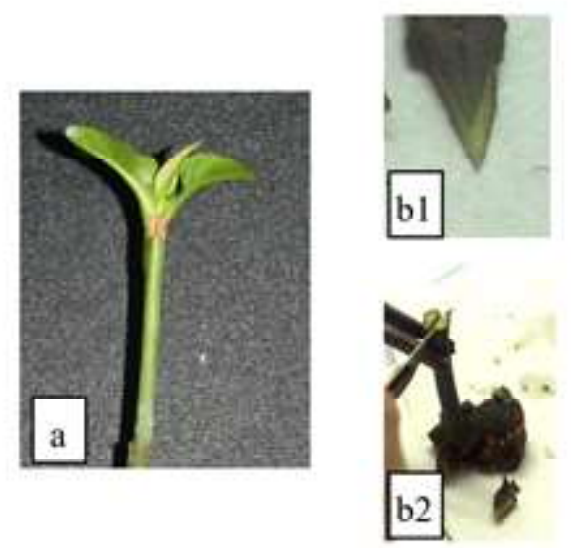

Bahan-bahan yang digunakan dalam penelitian ini adalah biji manggis yang didapatkan dari kebun rakyat Kabupaten Pidie Jaya Propinsi Aceh. Media tanam yang digunakan adalah media tanam tanah dan media tanam pasir. Alat yang digunakan terdiri atas gunting, silet, talenan, penggaris, tali raffia, gelas plastik, plastik bening ukuran $1 \mathrm{~kg}$, kertas label, serta kamera.

Percobaan ini menggunakan pola faktorial (2x2) dalam Rancangan Acak Kelompok (RAK) dengan diulang sebanyak 10 kali. Faktor pertama adalah sumber batang bawah terdiri dari 2 taraf yaitu tunas dari pesemaian biji utuh dan tunas dari pesemaian biji dibelah 2. Faktor kedua adalah jenis media tanam yaitu media tanam tanah dan media tanam pasir. Total perlakuan ada empat yang diulang sebanyak 10 kali, sehingga jumlah unit percobaan adalah 40 . Setiap unit percobaan hasil sambungan ditanam pada wadah gelas plastik dengan jumlah 1 tanaman per wadah.

Tanaman manggis sumber batang atas maupun batang bawah berasal biji manggis yang dikecambahkan
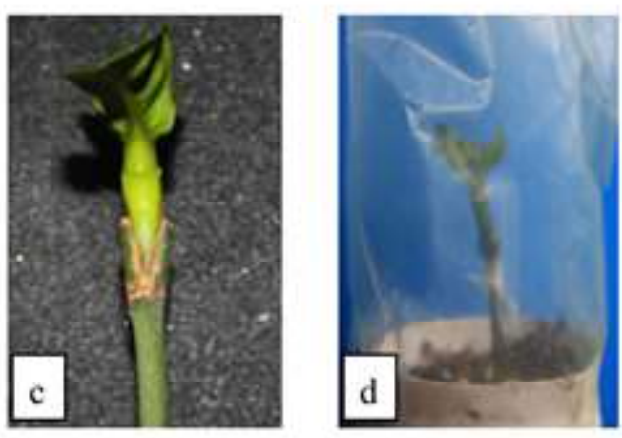

Gambar 1. Proses sambung mikro dengan cara sambung celah V: (a) tunas manggis di pesemaian, (b1) bagian bawah batang atas dibuat irisan $\mathrm{V}$, (b2) batang bawah dibuat potongan celah vertikal, (c) batang atas ditancapkan pada celah batang bawah, (d) hasil sambung mikro manggis di 
di polybag pesemaian. Proses sambung mikro dilakukan dengan cara sambung celah V (Gambar 1). Sumber batang atas berasal dari tunas manggis di pesemaian berumur 8 sampai 10 minggu. Batang bawah adalah tunas manggis hasil semai dari biji utuh dan biji belah dua (sesuai perlakuan). Tanaman manggis batang atas dan batang bawah yang digunakan pada penelitian ini berumur 8 sampai 10 minggu setelah semai, tinggi tanaman minimal $3 \mathrm{~cm}$, dan memiliki sepasang daun. Batang atas dipotong horizontal dengan ukuran panjang tunas sekitar $3 \mathrm{~cm}$. Bagian bawah batang atas dibuat irisan bentuk baji (huruf V) sepanjang $0,3 \mathrm{~cm}$. Batang bawah dipotong horizontal $3 \mathrm{~cm}$ dari permukaan tanah lalu dibuat celah vertikal sedalam $0,3 \mathrm{~cm}$ untuk tempat menjepit tunas batang atas. Batang atas lalu ditancapkan pada celah batang bawah lalu dilakukan pengikatan dengan plastik elastis di daerah sambungan. Setelah tahap sambung mikro, tunas ditumbuhkan pada media di pesemaian, lalu diberi sungkup plastik dan diletakkan di tempat yang teduh.

Pengamatan dilakukan selama delapan minggu. Peubah yang diamati adalah persentase tumbuh tunas, waktu tumbuh tunas, panjang tunas, dan jumlah pasangan daun hasil sambung mikro di pesemaian. Data hasil pengamatan dianalisis secara statistik dengan menggunakan analisis ragam. Jika hasil uji $\mathrm{F}$ menunjukkan adanya pengaruh yang nyata antar perlakuan, maka analisis dilanjutkan dengan Uji DMRT (Duncan's Multiple Range Test) pada taraf 5\%. Analisis data dilakukan dengan menggunakan software SAS v 9.13 portable.

\section{HASIL DAN PEMBAHASAN}

\section{Hasil}

Hasil sidik ragam menunjukkan bahwa tidak terdapat pengaruh interaksi antara perlakuan pembelahan biji manggis dan media tanam terhadap peubah persentase dan waktu tumbuh tunas. Perlakuan pembelahan biji manggis berpengaruh terhadap waktu tumbuh tunas tanaman manggis namun tidak menujukkan pengaruh pada persentase tumbuh tunas. Perlakuan jenis media tidak berpengaruh terhadap peubah persentase dan waktu tumbuh tunas (Tabel 1). Tabel 1 menunjukkan bahwa walaupun perlakuan biji utuh pada sambung mikro di pesemain memiliki waktu tumbuh tunas lebih cepat daripada

Tabel 1. Pengaruh pembelahan biji manggis dan media tanam terhadap persentase dan waktu tumbuh tunas sambung mikro manggis di pesemaian

\begin{tabular}{lcc}
\hline \multicolumn{1}{c}{ Perlakuan } & Persentase Tumbuh Tunas (\%) & Waktu Tumbuh Tunas (HST) \\
\hline Biji Utuh & $80,55 \mathrm{a}$ & $7,62 \mathrm{~b}$ \\
Biji Belah Dua & $71,99 \mathrm{a}$ & $8,53 \mathrm{a}$ \\
\hline Media Tanah & $80,55 \mathrm{a}$ & $7,87 \mathrm{a}$ \\
Media Pasir & $74,99 \mathrm{a}$ & $8,26 \mathrm{a}$ \\
\hline
\end{tabular}

Keterangan : Angka yang diikuti oleh huruf yang sama pada kolom yang sama tidak berbeda nyata berdasarkan uji DMRT pada taraf 0,05 . 
perlakuan biji dibelah dua, namun keduanya memiliki persentase tumbuh tunas yang tidak berbeda secara statistik. Tanaman manggis hasil sambung mikro di pesemaian disajikan pada Gambar 2.

Hasil sidik ragam menunjukkan bahwa tidak ada pengaruh interaksi yang nyata antara perlakuan pembelahan biji manggis dengan media tanam terhadap peubah panjang tunas baru. Faktor pembelahan biji menunjukkan pengaruh pada peubah panjang tunas baru umur 6, 7 dan 8 MSP. Faktor media tanam menunjukkan pengaruh pada peubah panjang tunas baru umur 7 dan 8 MSP (Tabel 2).

Tabel 2 menunjukkan bahwa perlakuan biji utuh memiliki tunas baru lebih panjang daripada biji dibelah dua. Selain itu media tanah mampu menyebabkan tanaman manggis hasil sambung mikro di pesemaian memiliki tunas baru lebih panjang daripada yang ditanam di media pasir. Tunas bibit manggis hasil sambung mikro di pesemaian disajikan pada Gambar 3.

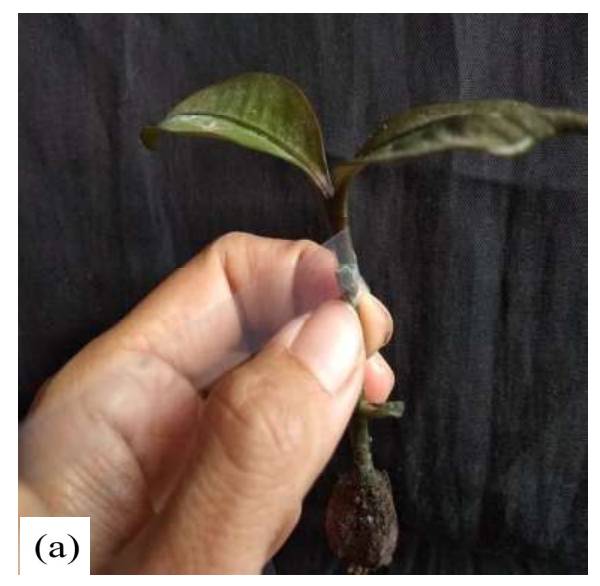

Gambar 3 menunjukkan bahwa perlakuan biji utuh menyebabkan hasil sambung mikro manggis di pesemaian memiliki jumlah pecah tunas lebih baik daripada perlakuan biji dibelah dua. Pada umur 2 bulan setelah sambung (BSP), sambung mikro manggis di pesemaian yang berasal dari perlakuan biji utuh sudah mengalami dua kali pecah tunas, sedangkan perlakuan biji dibelah dua baru satu kali pecah tunas.

Hasil sidik ragam menunjukkan bahwa tidak ada pengaruh interaksi antara perlakuan pembelahan biji dengan media tanam pada peubah jumlah daun. Pengaruh perlakuan hanya terlihat pada faktor pembelahan biji 6 dan 8 MSP (Tabel 3). Tabel 3 menunjukkan bahwa perlakuan pembelahan biji manggis memberikan pengaruh terhadap jumlah daun hasil sambung mikro di pesemaian. Tanaman manggis hasil sambung mikro di pesemaian yang batang bawahnya berasal dari biji utuh memiliki jumlah daun lebih banyak daripada biji dibelah dua (6 dan 8 MSP). Perlakuan media tanam tidak memberikan

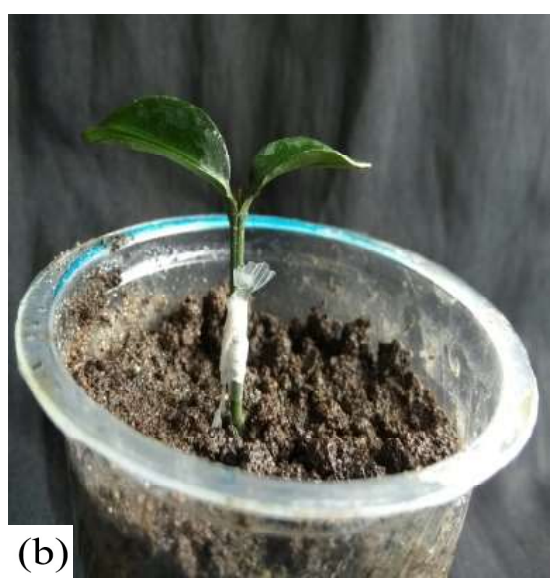

Gambar 2. Tanaman manggis hasil sambung mikro: (a) tanaman yang sudah disambung dan diikat dan (b) tanaman yang sudah ditanam dalam gelas plastik sebelum ditutup plastik bening 
Tabel 2. Pengaruh pembelahan biji manggis dan media tanam terhadap panjang tunas sambung mikro manggis di pesemaian

\begin{tabular}{lcccccc}
\hline \multirow{2}{*}{ Perlakuan } & \multicolumn{7}{c}{ Panjang Tunas (cm) } \\
\cline { 2 - 7 } & 3 MSP & 4 MSP & 5 MSP & 6 MSP & 7 MSP & 8 MSP \\
\hline Biji Utuh & $1,62 \mathrm{a}$ & $1,68 \mathrm{a}$ & $1,77 \mathrm{a}$ & $1,87 \mathrm{a}$ & $2,05 \mathrm{a}$ & $2,16 \mathrm{a}$ \\
Biji Belah Dua & $1,29 \mathrm{a}$ & $1,33 \mathrm{a}$ & $1,44 \mathrm{a}$ & $1,53 \mathrm{~b}$ & $1,67 \mathrm{~b}$ & $1,73 \mathrm{~b}$ \\
\hline Media Tanah & $1,60 \mathrm{a}$ & $1,64 \mathrm{a}$ & $1,74 \mathrm{a}$ & $1,84 \mathrm{a}$ & $2,03 \mathrm{a}$ & $2,11 \mathrm{a}$ \\
Media Pasir & $1,33 \mathrm{a}$ & $1,37 \mathrm{a}$ & $1,47 \mathrm{a}$ & $1,55 \mathrm{a}$ & $1,69 \mathrm{~b}$ & $1,79 \mathrm{~b}$ \\
\hline
\end{tabular}

Keterangan : Angka yang diikuti oleh huruf yang sama pada kolom yang sama tidak berbeda nyata berdasarkan uji DMRT pada taraf 0,05 .
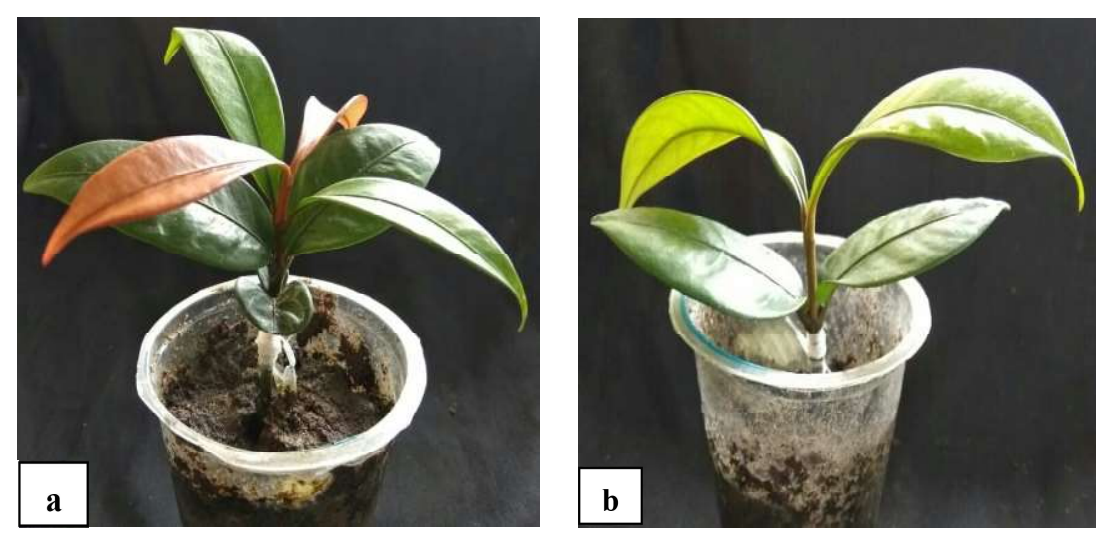

Gambar 3. Tunas bibit manggis hasil sambung mikro di pesemaian umur 2 bulan setelah sambung (BSP): (a) bibit manggis dari batang bawah asal biji utuh dan (b) biibit manggis dari batang bawah asal biji belah dua.

pengaruh terhadap jumlah daun hasil sambung mikro di pesemaian.

\section{Pembahasan}

Perlakuan pembelahan biji pada sambung mikro manggis di pesemaian menunjukkan bahwa biji utuh memiliki waktu pecah tunas lebih cepat, tunas baru lebih panjang (6, 7, $8 \mathrm{MSP})$, dan jumlah daun lebih banyak (6 dan 8 MSP) daripada biji dibelah dua (Tabel 1,2 dan 3). Hasil penelitian menunjukkan bahwa sambung mikro manggis di pesemaian yang berasal dari perlakuan biji utuh pada umur 2 BSP sudah mengalami dua kali pecah tunas, sedangkan perlakuan biji dibelah dua baru satu kali pecah tunas (Gambar 3).

Waktu muncul tunas baru yang lebih cepat terdapat pada perlakuan biji utuh karena biji utuh memiliki cadangan makanan lebih banyak daripada biji dibelah dua dan kuatnya dominansi apikal pada biji utuh (Agustina et al., 2020; Handayani et al., 2013). Pada proses sambung mikro yang berasal dari biji utuh, tunas yang tumbuh tetap berbatang tunggal, tidak ada tunas baru yang tumbuh dari bagian dasar biji. Pada sambung mikro yang berasal biji belah dua seringkali muncul tunas baru dari dasar biji, sehingga nutrisi biji 
akan terbagi dengan banyaknya jumlah tunas yang tumbuh, tunas tumbuh lebih banyak namun pendek. Pada perlakuan biji dibelah dua kemungkinan pemotongan biji menyebabkan hilangnya dominansi apikal sehingga pada sebagian biji yang dibelah, tunas yang tumbuh lebih dari satu.

Persentase keberhasilan sambungan dipengaruhi oleh umur fisiologis batang atas maupun batang bawahnya. Sambung mikro manggis yang dilakukan pada tunas-tunas muda hasil perkecambahan biji (in vitro atau semai) sebagai batang bawah maupun batang atas, memiliki tingkat keberhasilan yang tinggi (Handayani, 2012).

Batang atas dan batang bawah yang masih muda proses penyembuhan lukanya terjadi sangat cepat (Handayani et al., 2013). Pada proses penyembuhan jaringan yang terluka, pembentukan graft unionnya lebih sempurna. Sel-sel pada batang bawah dan batang atas saling kontak, menyatu, dan membaur. Sel-sel parenkim yang terbentuk dan terdeferensiasi akan membentuk kambium sebagai lanjutan dari lapisan kambium batang bawah dan batang atas yang lama. Dari lapisan kambium akan terbentuk jaringan pembuluh sehingga proses translokasi hara dari batang bawah ke batang atas atau sebaliknya hasil fotosintesis dari batang atas ke batang bawah berlangsung sebagaimana mestinya Miguelez-Sierra et al (2017).

Menurut Mangoendidjojo (2003), ada beberapa faktor yang perlu diperhatikan dalam melakukan penyambungan, yaitu hubungan kekerabatan antara batang atas dan batang bawah, teknik atau ketrampilan dalam melakukan penyambungan, kondisi lingkungan, serta keadaan batang atas dan batang bawah yang digunakan. Tingkat keberhasilan penyambungan antara lain dipengaruhi oleh ketepatan penyambungan antara batang atas dan dengan batang bawah sehingga jaringan kambium dan jaringan vaskular antara kedua batang dapat menempel dengan sempurna dan terhindar dari proses oksidasi yang dapat mengakibatkan pengeringan jaringan pada daerah pertautan (graft union) (Devy et al., 2011). Penelitian yang dilakukan memperlihatkan ukuran

Tabel 3. Pengaruh pembelahan biji manggis dan media tanam terhadap jumlah daun sambung mikro manggis di pesemaian

\begin{tabular}{lccc}
\hline \multirow{2}{*}{ Perlakuan } & \multicolumn{3}{c}{ Jumlah Daun } \\
\cline { 2 - 4 } & 4 MSP & 6 MSP & 8 MSP \\
\hline Biji Utuh & $2,90 \mathrm{a}$ & $3,50 \mathrm{a}$ & $3,58 \mathrm{a}$ \\
Biji Belah Dua & $2,80 \mathrm{a}$ & $2,92 \mathrm{~b}$ & $3,04 \mathrm{~b}$ \\
\hline Media Tanah & $2,86 \mathrm{a}$ & $3,32 \mathrm{a}$ & $3,43 \mathrm{a}$ \\
Media Pasir & $2,84 \mathrm{a}$ & $3,09 \mathrm{a}$ & $3,17 \mathrm{a}$ \\
\hline
\end{tabular}

Keterangan : Angka yang diikuti oleh huruf yang sama pada kolom yang sama tidak berbeda nyata berdasarkan uji DMRT pada taraf 0,05 . 
batang bawah memiliki ukuran yang sama dengan batang atas. Hal ini sejalan dengan penelitian Raharjo et al. (2013) yang menyebutkan bahwa ukuran yang sama antara batang bawah dengan batang atas cenderung meningkatkan keberhasilan penyambungan.

Perlakuan jenis media hanya menunjukkan pengaruh pada peubah panjang tunas baru 7 dan 8 MSP(Tabel2). Tanaman manggis hasil sambung mikro yang ditanam pada media tanah memiliki tunas baru lebih panjang dari pada media pasir. Hal ini karena tanah memiliki nutrisi yang lebih banyak dan mampu menyerap air lebih baik daripada pasir. Hal ini juga berkenaan dengan keseimbangan antara source, yaitu ketersediaan karbohidrat dan sink, yaitu yang menggunakan karbohidrat. Apabila jumlah sink lebih besar dibandingkan dengan source, maka keberhasilan penyambungan maupun kualitas pertautan antara batang bawah dan batang atas kurang baik. Suryadi (2009) menyatakan bahwa keberhasilan penyambungan maupun kualitas pertautan sambungan batang atas dan batang bawah ditentukan oleh keseimbangan antara source (ketersediaan karbohidrat) dan sink yang menggunakan karbohidrat. Untuk mendapatkan keberhasilan yang tinggi dan kualitas sambungan yang baik diperlukan produksi kalus yang cukup banyak, baik dari batang bawah maupun dari batang atas. Ketersediaan karbohidrat yang cukup akan mendorong produksi kalus yang cukup banyak.

\section{KESIMPULAN}

Pembelahan biji menurunkan keberhasilan sambung mikro manggis di pesemaian. Tanaman hasil sambung mikro di pesemaian yang berasal dari perlakuan biji utuh memiliki waktu tumbuh tunas lebih cepat, tunas baru lebih panjang (6, 7, $8 \mathrm{MSP})$, dan jumlah daun lebih banyak (6 dan 8 MSP) dibandingkan perlakuan biji dibelah dua. Perlakuan media hanya memberikan pengaruh pada peubah panjang tunas baru 7 dan 8 MSP. Media tanah menyebabkan tanaman manggis hasil sambung mikro di pesemaian memiliki tunas baru lebih panjang daripada di media pasir.

\section{DAFTAR PUSTAKA}

Agustina, M., Maisura, R.S. Handayani. 2020. The Effect of Different Seed Cutting Treatments and Concentrations of BAP for the Successful In Vitro Micrografting of Mangosteen (Garcinia mangostana L.). Journal of Tropical Horticulture. 3 (1):38-42

Devy N.F., A. Sugiyatno, F.Yulianti. 2011. Daya tumbuh tanaman jeruk kalamondin hasil perbanyakan via somatik embriogenesis in vitro pada batang bawah. JC. JHort. 21 (3):214-224.

Handayani, R.S. 2012. Rekayasa teknologi sambung mikro dan setek mikro pada tanaman manggis (Garcinia mangostana). [Disertasi]. Bogor: Institut Pertanian Bogor, Program Pascasarjana. 127 hal.

Handayani, R.S. 2013. Pengaruh Berbagai Jenis Substrat Untuk Menginduksi Perakaran Setek Mikro Tanaman Manggis (Garcinia mangostana) Secara In Vitro. Jurnal Samudera, 7 (2) : 281-290.

Handayani, R.S., R. Poerwanto, Sobir, A. Purwito, T.M. Ermayanti. 2013. Pengaruh Batang Bawah dan Jenis Tunas Pada Mikrograftting 
Manggis (Garciniamangostana L.) Secara In Vitro. J. Agron. Indonesia. 41(1):47-53.

Handayani, I., L. Nazirah, R.S. Handayani. 2020. The Effect of BAP and IBA on In Vitro Root Cultures of Acehnese Pomelo (Citrus maxima (Burm.) Merr.) Journal of Tropical Horticulture.3(1):38-42

Mangoendidjojo W. 2003. Dasar-dasar Pemuliaan Tanaman. Yogyakarta: Penerbit Kanisius. hlm 130-152.

Miguelez-Sierra, Y., A. Hernandez-Rodriguez, Y. Acebo-Guerrero, M. Baucher, M.El Jaziri. 2017. In Vitro Micrografting of Apical andAxillary Buds of Cacao. The Journal of Horticultura Science and Biotechnology. 92(1): 25-30.

Naz, A.A., M.J. Jaskani, H. Abbas, M. Qasim. 2007. In vitro studies on micrografting technique in two cultivars of citrus to produce virus free plants. Pak. J. Bot. 39(5):1773-1778.

Qosim, W., R. Poerwanto, G.A. Wattimena, Witjaksono. 2007. Pengaruh Iradiasi Sinar Gamma terhadap Kapasitas Regenerasi Kalus Nodular Tanaman Manggis. Hayati Journal of Biosciences.14(4):140-144.

Raharjo, M., E. Djauharia, I. Darwati, S.M.D. Rosita. 2016. Pengaruh umur batang bawah terhadap pertumbuhan benih mengkudu tanpa biji hasil grafting. Buletin Penelitian Tanaman Rempah dan Obat. 24(1):14-18.
Rahman, N., H.Fitriani, S.N. Hartati, E. Soedarmonowati. 2017. Multiplikasi Tunas Kultur Ubi Kayu dengan Teknik Sambung Pucuk (Grafting) in Vitro. Prosiding Seminar Nasional : Pertanian dan Tanaman Herbal Berkelanjutan di Indonesia. jurnal.umj.ac.id/index.php/semnastan/LIPI Bogor, hal. 229-236.

Ruhnayat, A., M. Syakir. 2014. Penyediaan Benih Jambu Mete Unggul Secara Cepat Melalui Mikro Grafting. Sirkuler. Informasi Teknologi Tanaman Rempah dan Obat. Balittro Kementan RI, Bogor. 26 hal.

Sinaga, S., Sobir, R. Poerwanto, H. Aswidinnoor, D. Duryadi. 2016. Genetic Variability Analysis On Apomictic Mangosteen (Garcinia mangostana) In Indonesia And its Close Related Species By Using RAPD Markers. Floribunda. 3(3):77-84

Suryadi, R. 2009. Pengaruh Jumlah Tunas dan Jumlah Daun terhadap Keberhasilan Penyambungan Jambu Mete (Anacardium occidentale L.) di Lapangan. Balai Penelitian Tanaman Obat dan Aromatik Bogor. Buletin Littro. 20(1):41-49.

Tirtawinata, M.R. 2003. Kajian anatomi dan fisiologi sambungan bibit manggis dengan beberapa kerabat Clusiaceae [disertasi]. Bogor: Institut Pertanian Bogor, Program Pascasarjana. 171 hal. 